[Agr. Biol, Chem., Vol. 31, No. 11, p. 1337 1342, 1967]

\title{
Studies on the Utilization of Hydrocarbons by Microorganisms
}

\author{
Part X. Screening of Aromatic Hydrocarbon-Assimilating \\ Microorganisms and $p$-Toluic Acid Formation \\ from $p$-Xylene
}

\author{
By Toshio OMori, Sadayuki Horiguchi and Koichi Yamada \\ Department of Agricultural Chemistry, Faculty of Agriculture, \\ The University of Tokyo, Tokyo \\ Received June 16, 1967
}

\begin{abstract}
In the course of investigation of aromatic hydrocarbon-utilizing bacteria, a certain strain S668B2 was found to produce a large amount of $p$-toluic acid from $p$-xylene.

Strain S668B2 was shown to be capable of producing an ultraviolet-absorbing substance from $p$-xylene. This substance was isolated in the form crystal and identified to $p$-toluic acid by several observations.

From the results of taxonomic studies on $5668 \mathrm{~B} 2$, it was identified to be Psuedomonas species.

The optimal medium composition and culture condition were studied in order to increase $p$-toluic acid production. The addition of $\mathrm{CaCO}_{3}$ was favorable for the $p$-toluic acid production. The amount of $p$-toluic acid formation increased from $0.4 \mathrm{~g} / 1$ to $3.4 \mathrm{~g} / 1$ after the investigation of optimal culture condition.
\end{abstract}

\section{INTRODUCTION}

The utilization of various hydrocarbons by microorganisms has recently received a good deal of attention. Especially the studies on fermentative production of amino acids and cells from $n$-alkane were carried out by several groups of workers. ${ }^{123}$ In spite of these many reports, there are few concerning the industrial application of aromatic hydrocarbons. Only the formation of salicylic acid from naphthalene ${ }^{4 \prime}$ and of cumic acid from $p$-cymene ${ }^{5)}$ have been almost exclusively investigated. While, in recent years, increasing

1) K. Yamada, J. Takahashi, K. Kobayashi and Y. Imada, This Journal, 27, 390 (1963).

2) K. Yamada, J. Takahashi and K. Kobayashi, This Journal, 27, 773 (1963).

3) J. Takahashi, K. Kobayashi, Y. Imada and

K. Yamada, This Journal, 27, 836 (1963).

4) P. Hsler, Biotech. Bioeng., 5, 243 (1963).

5) K. Yamada, S. Horiguchi and J. Takahashi, This Journal, 29, 943 (1965). interest has been shown in the microbial conversion of organic compounds, yet there is no systematic study on the transformation and assimilation of aromatic hydrocarbons, such as methylbenzenes, by microorganisms. So this work was initiated to form a part of above program. This report deals with the identification of newly isolated microorganisms, microbial formation of $p$-toluic acid from $p$-xylene and some observations on the $p$-toluic acid production.

\section{MATERIALS AND METHODS}

Microorganisms. A bacterial strain $\mathrm{S} 668 \mathrm{~B} 2$ was isolated from soil of rice field by a sceening procedure using $p$-xylene as the sole source of carbon. Diagnostic tests for the morphological studies were carried out mainly according to the "Manual of Microbiological Methods," 1957, Society of American Bacteriologists, and referred to the "Bergey's Manual of Determinative Bacteriology", 7th Ed., 1957. 


\section{Table I. Solvfnt Systems and Developing Reagents for the Detection} of Metabolic Product

Solvent

1. $\left(\mathrm{NH}_{4}\right)_{2} \mathrm{CO}_{3}-\mathrm{NH}_{4} \mathrm{OH}-n$-Butanol*

2. n-Butanol: Acetic acid : Water $(3: 2: 95)$

3. n-Butanol : Acetic acid : Water $(4: 1: 2)$

\author{
Reagent \\ B.C.G. \\ Diazotized Benzidine** \\ UV Ray Irradiation \\ Ninhydrin
}

Metabolic Product

Organic Acid

Phenolic compound UV-Rayabsorbing compound

Amino acid

* n-Butanol was saturated with ammonia/ammonium carbonate.

** A : Five grams of benzidine was dissolved in $14 \mathrm{ml}$ of concentrated hydrochloric acid and the solution was filled up to 11 with water.

B : Ten per cent sodium nitrite solution in water. The solutions A and B were mixed at equal volume before spraying.

Media. The composition of screening medium was as follows $p$-Xylene $20 \mathrm{ml} / 1, \mathrm{NH}_{4} \mathrm{NO}_{3} 4.0 \mathrm{~g} \quad \mathrm{KH}_{2} \mathrm{PO}_{4}$ $1.5 \mathrm{~g}, \mathrm{Na}_{2} \mathrm{HPO}_{4} 1.5 \mathrm{~g}, \mathrm{MgSO}_{4} \cdot 7 \mathrm{H}_{2} \mathrm{O} 0.2 \mathrm{~g}, \mathrm{FeSO}_{4} \cdot 7 \mathrm{H}_{2} \mathrm{O}$ $0.005 \mathrm{~g}, \quad \mathrm{MnSO}_{4} \cdot 4 \mathrm{H}_{2} \mathrm{O} 0.002 \mathrm{~g}, \mathrm{CaCl}_{2} \cdot 2 \mathrm{H}_{2} \mathrm{O} \quad 0.01 \mathrm{~g}$, Yeast ext. $0.5 \mathrm{~g}$ and distilled water to make 11 .

After culture conditions were investigated, the optimal composition of the medium was established as follows: p-Xylene $20 \mathrm{ml} / \mathrm{l},\left(\mathrm{NH}_{2}\right)_{2} \mathrm{CO} 4.0 \mathrm{~g}, \mathrm{KH}_{2} \mathrm{PO}_{4}$ $1.5 \mathrm{~g}, \mathrm{NaHPO}_{4} 1.5 \mathrm{~g}, \mathrm{MgSO}_{4} \cdot 7 \mathrm{H}_{2} \mathrm{O} 0.2 \mathrm{~g}, \mathrm{FeSO}_{4} \cdot 7 \mathrm{H}_{2} \mathrm{O}$ $0.001 \mathrm{~g}, \mathrm{CaCl}_{2} \cdot 2 \mathrm{H}_{2} \mathrm{O} 0.01 \mathrm{~g}$, Yeast ext. $0.5 \mathrm{~g}, \mathrm{CaCO}_{3}$ $40 \mathrm{~g}$, distilled water to make 11 and $\mathrm{pH}$ was adjusted to 7. A five hundred milliliter-flask containing $50 \mathrm{ml}$ of the medium was autoclaved at $115^{\circ} \mathrm{C}$ for 10 minutes. Before cultivation $1.0 \mathrm{ml}$ of sterile hydrocarbon was added to the medium in the flask.

Cultivation. A loop of cells grown on $p$-xyleneagar-slant for 2 days was inoculated and incubated at $30^{\circ} \mathrm{C}$ on reciprocal shaker for 24 hours during the investigation of the culture conditions.

Hydrocarbons. All of the hydrocarbons (toluene, $p$-xylene, $m$-xylene, $o$-xylene, ethylbenzene, $m$ - and $p$ diethylbenzene) were obtained from Tokyo Chemical Industry Co., Ltd., and used without further purification.

Paper Chromatography. Paper chromatography of the ascending technique was employed for the detection of metabolic products. Solvents systems used $^{(-7)}$ are listed in Table I. The spots were visualized by ultraviolet irradiation and/or by spraying the developing reagent (Table I). Toyo filter paper No. 50 was used.

Determination of Growth Cell and Acid produced. Cell growth was determined by weighing dried cells.

6) M. E. Fewster and D. A. Hall, Nature (Lond.), 168, 78 (1951).

7) M. S. Bardinskaya and T. A. Shubert, Biokhimija, 27, 58 (1962).

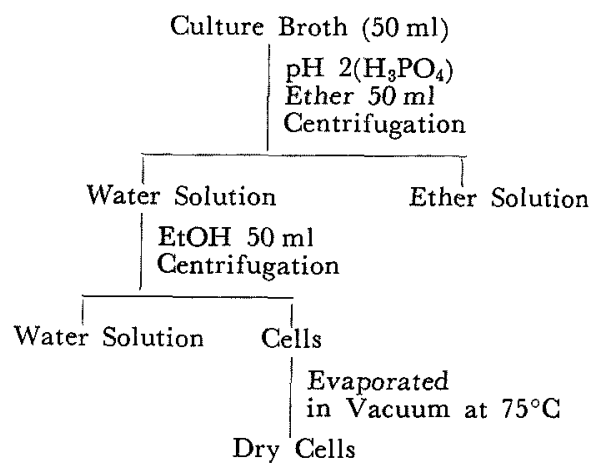

FIG. 1. Procedure for the Determination of Cell Growth and Acid Produced.

Usually main part of cells did not precipitate to the bottom of culture broth through the centrifugation so long as $p$-xylene substrate remained. Therefore the amount of cells was determined according to the procedure presented in Fig. 1. Also p-toluic acid produced in culture broth was extracted by equal volume of ether as shown in Fig. 1.

The ether solution was titrated by $\mathrm{NaOH}$ (N/100, $\mathrm{N} / 50, \mathrm{~N} / 20$ ) and then the amount of acid produced was calculated from the titration value.

\section{RESUTS AND DISCUSSION}

\section{Isolation of Microorganisms from Soil}

Accumulation culture was carried out by adding $0.1 \mathrm{~g}$ of soil sewage sample into $5 \mathrm{ml}$ of medium in a test tube. After second accumulation culture microorganisms were isolated by the general method.

Seven microorganisms were obtained from sevently enriched cultures. But only one of them showed good growth in liquid medium. 
TABLE II. ASSIMILATION OF HYDROCARBONS BY ISOLATED BACTERIA

\begin{tabular}{lc}
\multicolumn{1}{c}{ Substrate } & Growth \\
Toluene & - \\
$p$-Xylene & + \\
$m$-Xylene & + \\
$o$-Xylene & - \\
Ethylbenzene & - \\
Diethylbenzene & - \\
1,2,3-Trimethylbenzene & - \\
1,2,4-Trimethylbenzene & + \\
1, 3, 5-Trimethylbenzene & - \\
$+:$ growth & - no growth
\end{tabular}

Table III. Descriptive Chart of The Isolated MICROORGANISMS (S668B2)

Rods, 0.6 by 1.2 to 1.6 microns. Motile with a polar flagellum. Spore not formed. Gram-negative.

Nutrient agar colonies: Circular, smooth, entire, convex, glistening, pale yellowish brown, butyrous.

Nutrient agar slant: Growth moderate, filiform, flat, glistening, pale yellowish brown.

Glutamate agar slant: Growth moderate, filiform, glistening, yellowish gray.

Nutrient broth: Strongly turbid.

Nutrient gelatin stab: Liquefaction.

B.C.P. milk: Alkaline, not peptonized.

Nitrite is not found after 1,3 and 5 days' incubation in nitrate broth.

Nitrate respiration: Positive.

Indole not produced.

Starch not hydrolyzed.

Acid but no gas is aerobically produced from gly. cerol, xylose, glucose and starch according to Hugh and Leifson's method. No acid and gas are anaerobically produced from the carbohydrates mentioned above.

Glucose, gluconate, citrate, succinate and $p$-hydroxybenzoate are utilized as a sole source of carbon with ammoniacal nitrogen.

Reducing substance is not produced from gluconate.

Soluble pigment is not produced on King's A and B media.

Grows well at $37^{\circ}$ and $42^{\circ} \mathrm{C}$.

Cytochrome oxidase: Positive.

Source: Soil.

And the strain (S668B2) was tested for its abilities to utilize the individual hydrocarbons. As shown in Table II, the strain (S668B2) utilized $p$-xylene, $m$-xylene and 1,2,4-trimethylbenzene as a sole source of carbon.

Taxonomical Studies of Microorganisms Isolated

From the results of taxonomic studies, shown in Table III, the strain S668B2 obviously belonged to Pseudomonas species. Through the results of physiological tests it seemed to be achromogenic variety of $P$ s. aeruginosa. But the strain differed from typical Pseudomonas aeruginosa in the following points; 1) 2-Ketogluconate was not formed from gluconate. 2) Gelatin was liquefied but milk was not peptonized. 3) Nitrate respiration was positive.

Determination of Metabolic Products. After 20 and 40 hours cultivation on $p$-xylene, the ether extract of the culture broth was submitted to paper chromatography. Bromcresol green-positive and ultraviolet-absorbing spot was detected. Usually other spot could not be found. The substance was isolated in crystalline form from the ether extraction of culture broth and was recrystallized from water. The paper chromatography was done on two kinds of solvent system shown in Table I. The $R_{F}$ values (solvent system $1,0.4$; solvent system $2,0.65$ ) were essentially the same with those of authentic $p$-toluic acid. The physical properties of the crystal which was recrystallized from water two times were compared with those of authentic $p$-toluic acid. As shown in Fig. 2 and 3, the product and authentic sample had identical infrared and ultraviolet ray absorption spectra and m.p. of $178^{\circ} \mathrm{C}$.

Also elementary analysis of the product was

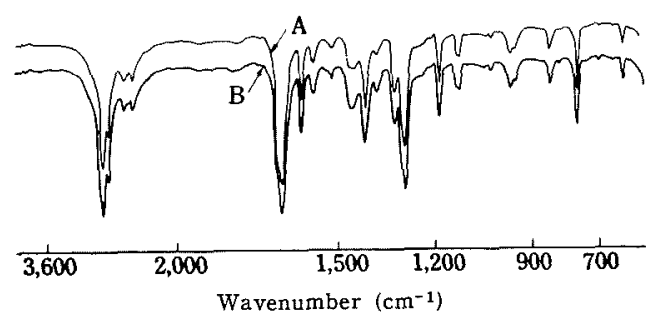

FIG. 2. Infrared Absorption Spectra of the Product
A: Authentic $p$-toluic acid
B: Product 


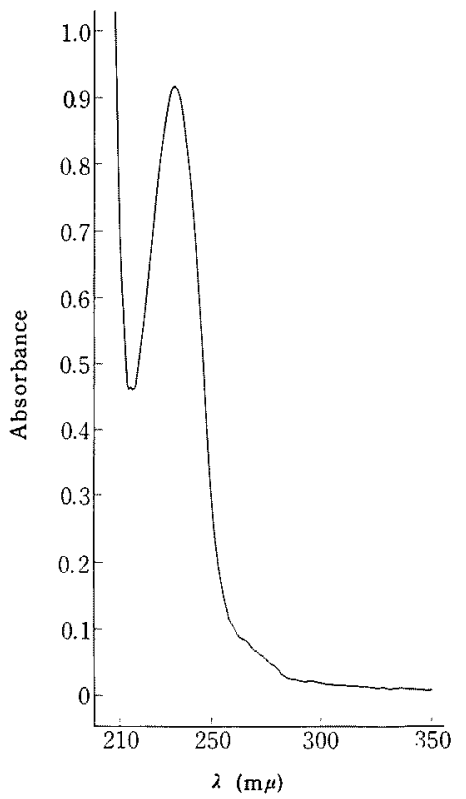

FIG. 3. Ultraviolet Absorption Spectra of the Product.

The sample was dissolved in $0.01 \mathrm{~N}-\mathrm{NaOH}$.

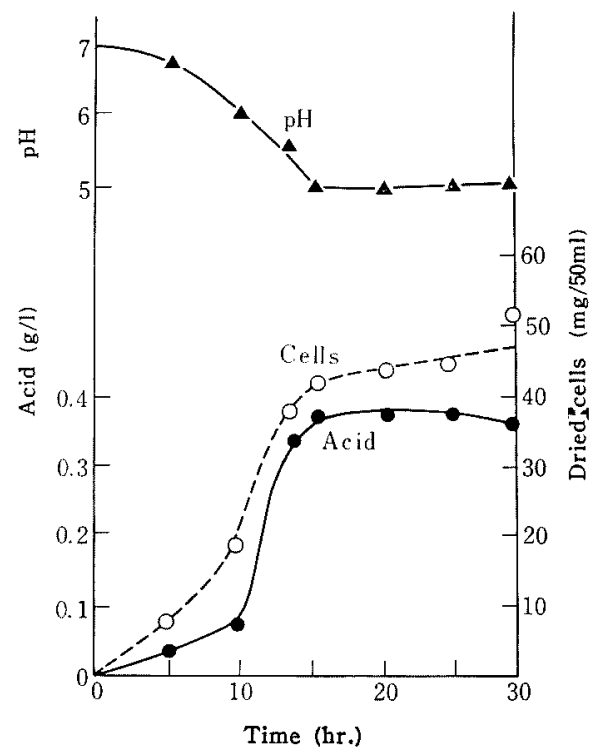

FIG. 4. Time Course of the Acid Production. in good agreement with the calculated value of the $p$-toluic acid (Found: $\mathrm{C}, 70.38 ; \mathrm{H}, 6.07$ Calcd. for: C, 70.58; H, 5.92; O, 23.50\%).

Some Observations Concerning $p$-Toluic Acid Production

The time course of the $p$-toluic acid production was pursued with the composition of screening medium. The growth curve, $p$-toluic acid production and change of $\mathrm{pH}$ are given in Fig. 4. From the results, a maximum amount of acid production was given at 15 hours after inoculation. Then the $\mathrm{pH}$ value of the culture broth moved downward with the acid production and showed 5.0 at the lowest. The cell growth had similar tendency with the curve of acid production.

Effect of Aeration and Agitation on $p$-Toluic acid Production

As the formation of $p$-toluic acid should be due to oxidative process, aeration and agitation seem to be essential factors. The aeration effect was investigated with varying the volume of medium within the range from $50 \mathrm{ml}$ to $300 \mathrm{ml}$ per $500-\mathrm{ml}$ flask. The results given in Table IV showed that aeration was effective for the higher acid formation. And also agitation had obvious effect on acid formation, which was concluded by comparing 170 and 120 reciprocations per minute. The results are listed in Table $\mathrm{V}$

TABLe IV. EFFect of Volume of Medium ON THE ACID PRoduction ( $\mathrm{mg} / \mathrm{l}$ )

Medium (ml/500-ml flask)

$\begin{array}{rl}50 & 410 \\ 100 & 450 \\ 200 & 380 \\ 300 & 300\end{array}$

Table V. EFFect of agitation on the ACID Production

$\begin{array}{cc}\text { Agitation } & \text { Acid found } \\ \text { (R.P.M.) }^{*} & (\mathrm{mg} / \mathrm{l}) \\ 120 & 370 \\ 170 & 530\end{array}$

* Reciprocations per minute 
Effect of Nitrogen Source on $p$-Toluic Acid Production

In order to find out the suitable nitrogen source for $p$-toluic acid production, various kinds of nitrogen source were examined by replacing ammonium nitrate with the same

Table VI. EFFect on NITRogen SOURCES ON THE ACID PRODUCTION

$\begin{array}{lcc}\begin{array}{c}\mathrm{N}-S o u r c e \\ (4 \mathrm{~g} / \mathrm{l})\end{array} & \mathrm{pH} & \begin{array}{c}\text { Acid found } \\ (\mathrm{mg} / \mathrm{l})\end{array} \\ \mathrm{NH}_{4} \mathrm{NO}_{3} & 5.4 & 490 \\ \mathrm{NH}_{4} \mathrm{Cl} & 5.4 & 260 \\ \left(\mathrm{NH}_{4}\right)_{2} \mathrm{SO}_{4} & 5.6 & 370 \\ \left(\mathrm{NH}_{4}\right)_{2} \mathrm{HPO}_{4} & 5.6 & 880 \\ \mathrm{NH}_{4} \mathrm{H}_{2} \mathrm{PO}_{4} & 5.6 & 920 \\ \mathrm{NaNO}_{3} & 7.0 & 370 \\ \left(\mathrm{NH}_{2}\right)_{2} \mathrm{CO} & 5.8 & 1080 \\ \text { Peptone } & 5.4 & 1240\end{array}$

Table VII. EFFect of Nitrogen ConcentraTION ON THE ACID PRODUCTION

\begin{tabular}{|c|c|c|c|}
\hline N. Source & $\mathrm{g} / \mathrm{l}$ & $\begin{array}{l}\text { Acid }(20 \mathrm{hr} .) \\
(\mathrm{mg} / \mathrm{l})\end{array}$ & $\begin{array}{l}\text { Acid }(40 \mathrm{hr} .) \\
(\mathrm{mg} / \mathrm{l})\end{array}$ \\
\hline$\left(\mathrm{NH}_{2}\right)_{2} \mathrm{CO}$ & $\begin{array}{l}1 \\
4 \\
8\end{array}$ & $\begin{array}{r}1040 \\
810 \\
820\end{array}$ & $\begin{array}{l}1100 \\
1100 \\
1110\end{array}$ \\
\hline
\end{tabular}

TABLE VIII. EFFECT OF MiNERAL SALTS ON THE ACID PRODUCTION

\begin{tabular}{|c|c|c|}
\hline Omission & Growth & Acid (mg/l) \\
\hline$-(\mathrm{Mg}+\mathrm{Mn}+\mathrm{Ca}+\mathrm{Fe})$ & - & - \\
\hline$-(\mathrm{Mn}+\mathrm{Ca}+\mathrm{Fe})$ & + & 240 \\
\hline$-(\mathrm{Mg}+\mathrm{Mn}+\mathrm{Ca})$ & + & 80 \\
\hline$-(\mathrm{Mg}+\mathrm{Mn}+\mathrm{Fe})$ & - & - \\
\hline$-(\mathrm{Mg}+\mathrm{Ca}+\mathrm{Fe})$ & - & - \\
\hline$-(\mathrm{Fe}+\mathrm{Ca})$ & + & 140 \\
\hline$-(\mathrm{Fe}+\mathrm{Mn})$ & + & 260 \\
\hline$-(\mathrm{Mg}+\mathrm{Mn})$ & + & 130 \\
\hline$-(\mathrm{Mg}+\mathrm{Ca})$ & + & 10 \\
\hline$-(\mathrm{Mg}+\mathrm{Fe})$ & + & 20 \\
\hline$-(\mathrm{Mn}+\mathrm{Ca})$ & + & 250 \\
\hline$-\mathrm{Fe}$ & + & 110 \\
\hline$-\mathrm{Mg}$ & + & 90 \\
\hline$-\mathrm{Mn}$ & + & 370 \\
\hline$-\mathrm{Ca}$ & + & 340 \\
\hline -Yeast ext.* & + & 390 \\
\hline $\begin{array}{ll}\mathrm{Mg}: & \mathrm{MgSO}_{4} \cdot 7 \mathrm{H}_{2} \mathrm{O} \\
\mathrm{Fe}: & \mathrm{FeSO}_{4} \cdot 7 \mathrm{H}_{2} \mathrm{O}\end{array}$ & $\begin{array}{ll}\mathrm{Mn}: \mathrm{M} \\
\mathrm{Ca}: \mathrm{C}\end{array}$ & $\begin{array}{l}\mathrm{O}_{4} \cdot 7 \mathrm{H}_{2} \mathrm{O} \\
\cdot 2 \mathrm{H}_{2} \mathrm{O}\end{array}$ \\
\hline
\end{tabular}

weight per cent of individual nitrogen source. As shown in Table VI, urea, ammonium phosphate and peptone were chosen as favorable nitrogen sources. Above all, urea was superior in reappearance to the others. The concentration of urea was also studied within the extent from $1 \mathrm{~g} / 1$ to $8 \mathrm{~g} / 1$ as presented in Table VII. But there was no difference in acid production regarding to the level of nitrogen concentration.

\section{Effect of Mineral Salts}

Omission test was carried out. The result is shown in Table VIII. MnSO $4 \mathrm{H}_{2} \mathrm{O}$ showed inhibitory effect, while $\mathrm{FeSO}_{4} \cdot 7 \mathrm{H}_{2} \mathrm{O}$ and $\mathrm{MgSO}_{4} \cdot 7 \mathrm{H}_{2} \mathrm{O}$ stimulatory. $\mathrm{CaCl}_{2} \cdot 2 \mathrm{H}_{2} \mathrm{O}$ had little effect. The investigation was made to find out the optimal concentration of $\mathrm{MgSO}_{4}$. $7 \mathrm{H}_{2} \mathrm{O}$ and $\mathrm{FeSO}_{4} \cdot 7 \mathrm{H}_{2} \mathrm{O}$. From these studies it was concluded that $\mathrm{MgSO}_{4} \cdot 7 \mathrm{H}_{2} \mathrm{O} 200 \mathrm{mg} / \mathrm{l}$ and $\mathrm{FeSO}_{4} \cdot 7 \mathrm{H}_{2} \mathrm{O} 1 \mathrm{mg} / \mathrm{l}$ were optimal concentration.

Effect of $\mathrm{pH}$ and $\mathrm{CaCO}_{3}$ on $p$-Toluic Acid Production

For the purpose of investigating the effect of $\mathrm{pH}$ on the formation of $p$-toluic acid, the initial $\mathrm{pH}$ of the culture medium was adjused

TABLE IX. EFFECT OF INITIAL pH ON THE ACID PRODUCTION

$\begin{array}{ccc}\text { Initial } \mathrm{pH} & \mathrm{pH} * & \text { Acid }(\mathrm{mg} / \mathrm{l}) \\ 9.0 & 9.0 & - \\ 8.0 & 5.4 & 720 \\ 7.0 & 5.2 & 350 \\ 6.0 & 5.2 & 250 \\ 5.0 & 5.0 & -\end{array}$

* pH after $20 \mathrm{hr}$. incubation

Ammonium nitrate was used as nitrogen source.

TABLE X. EFFECT OF INITIAL pH oN THE ACID PRODUCTION

$\begin{array}{ccc}\text { Initial } \mathrm{pH} & \mathrm{pH}^{*} & \text { Acid }(\mathrm{mg} / \mathrm{l}) \\ 9.0 & 9.0 & - \\ 8.0 & 7.4 & 540 \\ 7.0 & 6.9 & 900 \\ 6.0 & 5.7 & 430 \\ 5.0 & 5.0 & -\end{array}$

* pH: After 20 hr incubation.

Urea was used as nitrogen source. 
to $5,6,7,8$ and 9 . The results are given in Table IX. When ammonium nitrate was used as nitrogen source, the initial $\mathrm{pH} 8$ was suitable for the higher yield of acid. But during the early period of cultivation the cell growth was not so well and after 24 hours cultivation the $\mathrm{pH}$ value gradually fell down to 5.4. But when urea was used as nitrogen source, the initial $\mathrm{pH} 7$ was the most favorable for the higher production of the acid. The result is shown in Table X.

It was concluded that the initial $\mathrm{pH} 7$ was effective for the acid production. Also it was necessary to maintain $\mathrm{pH}$ value during cultivation to some degree higher than 6 . From the results of Fig. 4 and Tables IX and $X$, it appeared that the control of the $\mathrm{pH}$ value was necessary for the higher yield of the acid. So the $\mathrm{CaCO}_{3}$ was added for the maintenance of $\mathrm{pH}$. As shown in Fig. 5, the amount of the production of $p$-toluic acid increased by the addition of $\mathrm{CaCO}_{3}$. However there was no great difference among the concentrations of $\mathrm{CaCO}_{3}$ from $0.2 \%$ to $8 \%$ concerning the yield of the acid.

Consequently, it is concluded that the aeration and agitation are effective for the production of the acid and also that the control of $\mathrm{pH}$ value is important factor to improve the production of $p$-toluic acid from $p$-xylene. Further studies on the $p$-toluic acid formation from $p$-xylene including not only reaction mechanisms but also the relation between

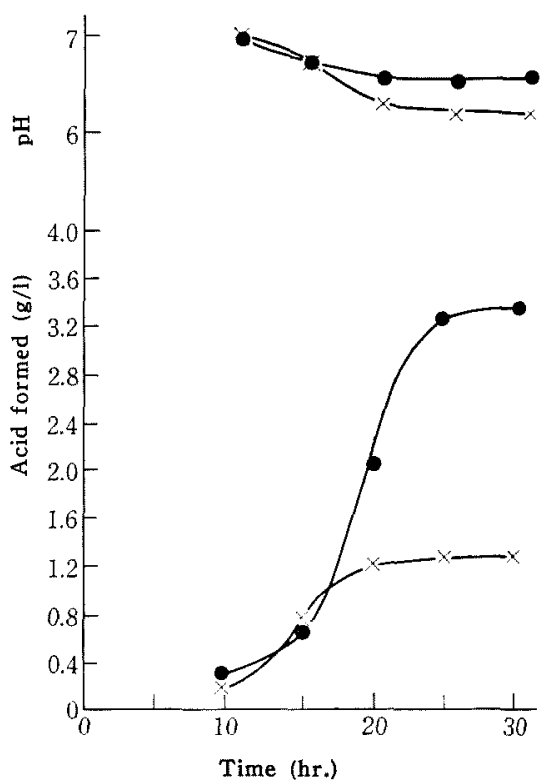

FIG. 5. Effect of $\mathrm{CaCO}_{3}$ on the Acid Production.

- $+\mathrm{CaCO}_{3}$ $x-\times-\mathrm{CaCO}_{3}$

Urea was used as nitrogen source.

substrates and organisms are in progress. The results will be shown elsewhere.

Acknow ledgement. Grateful acknowledgement is made to Dr. K. Komagata for the taxonomic studies.

This paper was read at the Annual Meeting of the Agric. Chem. Soc. Japan which was held at Tokyo on April 4th, 1967. 